\title{
El conde de Caylus y los orígenes del imaginario moderno
}

\author{
José Ignacio Gómez Álvarez*
}

$\begin{aligned} \text { RESUMEN: } & \text { ABSTRACT: } \\ \text { Se utilizan las distintas facetas } & \text { In this essay I will review } \\ \text { de la biografía del conde de Caylus } & \text { the different dimensions } \\ \text { (1692-1765) para determinar su } & \text { of count Caylus' biography } \\ \text { importancia histórica por su papel } & (1692-1765) \text { in order to analyse } \\ \text { jugado en el momento en el que } & \text { his historic importance at the } \\ \text { está naciendo el imaginario } & \text { moment of the birth of the } \\ \text { moderno, el museo imaginario que } & \text { museum without walls, } \\ \text { eclosiona en el siglo XX y del que } & \text { and Malraux. by Benjamin } \\ \text { hablan Benjamin y Malraux. } & \end{aligned}$

"La muerte nos ha librado del más cruel de los amateurs". Al morir el conde de Caylus, Diderot no fue especialmente benévolo con quien no queria ser más que un historiador a la manera antigua, cuando ese oscuro oficio ni siquiera se había inventado como tal. $Y$ con Diderot coincidía el menor de los Cochin, quien opinaba que las intervenciones de Caylus habian sido ruinosas para las artes. El corresponsal de Denis Diderot, el barón Friedrich Melchior von Grimm, también hostil al conde, por lo menos le dedicó una necrológica templada e incluso puede decirse que, por su mera existencia, laudatoria1. Pero esas opiniones han cambiado mayoritariamente desde entonces. Doscientos años después de la muerte del conde, Julius von Schlosser se refiere a él como "el erudito y genial conde Caylus"2.

* Doctorado Historia del Arte III - UCM

1 CAYLUS, Comte de: Vies d'artistes du XVIIE siècle. Discours sur la peinture et la sculpture. Salons (1751 et 1753). París, André Fontaine, 1910. Edición de H. LAURENS. pág. XVII.

2 SCHLOSSER, Julius von: La literatura artística: manual de fuentes de la Historia Moderna del Arte. Madrid, Cátedra, 1976. pág. 409. Francis HASKELL destaca su figura como «una de las más significativas e influyentes de la vida artistica de la Europa del siglo XVIII", en El laborioso nacimiento del libro de arte. Vitoria, Instituto de Estudios Iconográficos Ephialte, 1991. Nota 16. También alude al silencio que ha caido sobre su nombre desde que en 1889 Samuel ROCHEBLAVE fuera el último que de forma integral estudiara al conde (Essai sur le Comte de Caylus, l'homme, lantiste, l'antiquaire. París. Hachette, 1889). 
Anne-Claude-Philippe de Thubières de Grimoard de Pestels de Lévis, nacido en 1692, conde de Caylus, con grandeza de España, sobrino segundo por parte de madre, la influyente marquesa de Villette, de la esposa del rey Luis XIV, Madame de Maintenon; arqueólogo capaz de negociar con un grupo de bandidos para asegurarse un salvoconducto que le permitiera acceder a los lugares de Éfeso y Colofón; grabador de reproducciones de obras de artistas del Renacimiento; anticuario y coleccionista de piezas citadas por Winckelmann en su fundamental Historia del arte en la Antigüedad, escritor de novelas libertinas y de discursos para la Academia de la que fue nombrado amateur honorario y después académico de derecho; militar pese a su aversión por esa profesión; mecenas de artistas como Bouchardon y biógrafo de sus amigos Watteau y De Troy y de una veintena de artistas; diana de los dardos de Diderot, de Grimm, de Marmontel, de Cochin; muerto en 1765. El más cruel de los amateurs, el erudito y genial conde de Caylus.

Personaje controvertido, fruidor de todos los privilegios de su clase -incluyendo unos buenos ingresos privados, tiempo libre, la movilidad que se desprende de ellos y el acceso a artistas y coleccionistas ${ }^{3}$, puede afirmarse que Caylus ocupa un lugar relevante en el desarrollo de la modernidad aunque hoy haya caído en el olvido y resulte por ello difícil de situar, tan amable o desagradable como se le quiera hacer aparecer. El “déspota y huraño»4, el «desabrido y brusco»5 conde de Caylus.

En el estudio que sigue se intentará situar a Caylus en el origen de la época contemporánea en cuanto a la elaboración de su imaginario se refiere. El desafío es situarle, en el momento de la eclosión de la imagen pública, universal (por medio de la prensa periódica, del museo público, del libro ilustrado...), como impulsor del imaginario moderno, contemporáneo. Como artista, como connaisseur, como escritor, como coleccionista y como participante en el primer proyecto de crear un libro de Historia del arte con ilustraciones, como tratante de imágenes en suma, su figura parece especialmente idónea para estudiar el nacimiento del imaginario en el que nos movemos, al que Malraux llamara el museo imaginario y que desde entonces no ha parado de crecer. Se contempla así su biografía como lugar de encuentro de realidades históricas a la vez que como generadora de cambios. $Y$ el esquema sobre el que se trabaja es el siguiente:

3 RICE, Danielle: “Caylus», en TURNER, Jane (ed.): The Dictionary of Art. Londres, Macmillan, 1996.

4 CAYLUS, C. de: op.cit., pág. VIII.

5 Según se lee en uno de los versos del epitafio burtón que Diderot compusiera para Caylus:

Ci-gît un antiquaire acariâtre et brusque.

Ah! qu'il est bien logé dans cette cruche étrusque! 


\begin{tabular}{|c|c|c|}
\hline $\begin{array}{l}\text { DiMENSIÓN PERSONAL } \\
\text { (BIOGRÁFICA) }\end{array}$ & $\begin{array}{l}\text { Dimensión PÚblica } \\
\text { (ÉvÉnementiel) }\end{array}$ & $\begin{array}{l}\text { DIMENSIÓN HISTÓRICA } \\
\text { (ESTRUCTURAL) }\end{array}$ \\
\hline ARTISTA & $\begin{array}{l}\text { Pintor y grabador de } \\
\text { originales y de copias. }\end{array}$ & $\begin{array}{l}\text { El nacimiento del libro } \\
\text { de arte ilustrado. }\end{array}$ \\
\hline ESCRITOR & $\begin{array}{l}\text { Sus libros y discursos. } \\
\text { La refutación de Lessing }\end{array}$ & $\begin{array}{l}\text { Ni poesía muda ni } \\
\text { pintura hablada. }\end{array}$ \\
\hline $\begin{array}{r}\text { COLECCIONISTA Y } \\
\text { PROMOTOR DE } \\
\text { LAS ARTES }\end{array}$ & $\begin{array}{l}\text { Su colección privada } \\
\text { y los concursos que } \\
\text { patrocina. }\end{array}$ & $\begin{array}{l}\text { El nacimiento del } \\
\text { museo, de las } \\
\text { exposiciones y del } \\
\text { público. }\end{array}$ \\
\hline $\begin{array}{r}\text { FORTUNA } \\
\text { CRITICA }\end{array}$ & $\begin{array}{l}\text { Los ataques de } \\
\text { Diderot, Winckelmann, } \\
\text { Hulst, Marmontel y } \\
\text { Lessing y su muerte } \\
\text { historiográfica. }\end{array}$ & $\begin{array}{l}\text { El nacimiento de la } \\
\text { Historia del Arte de la } \\
\text { crítica del arte y el } \\
\text { cambio de ciclo } \\
\text { artístico. }\end{array}$ \\
\hline
\end{tabular}

\section{Caylus, el artista, en un proyecto pionero}

Uno de los proyectos más interesantes del siglo XVIII, y de toda la historia del arte sin duda, es la elaboración del Recueil Crozat. Se conoce con este nombre el proyecto de edición del primer libro ilustrado sobre Historia del arte, entendida ésta como recuento de las principales obras de la creatividad humana, que el mayor coleccionista francés del siglo XVIII, Pierre Crozat (1665-1740), llevó a cabo desde el año 1721 hasta su muerte. Dos años después de ésta vería la luz el segundo de los volúmenes programados y no en la forma que se esperaba. Inicialmente se contemplaban más pero el proyecto de Crozat quedó inacabado. Este banquero amasó su fortuna en la ciudad de Toulousse y posteriormente se trasladó a París, donde ocupó el cargo de Tesorero de Francia. Crozat patrocinó allí a un gran número de artistas como La Fosse, Watteau, De Troy, Rosalba Carriera y Boucher, algunos de los cuales se alojaron durante un tiempo en su mansión. Pero, lógicamente, no eran sólo artistas los que componian su círculo; también participaban en las reuniones organizadas en su galería de dibujos algunos de los amateurs principales, como Pierre-Jean Mariette, Jean de Jullienne, Louis-Petit de Bachaumont, el abate de Marolles, Hulst o el propio Caylus. El proyecto consistía en la ilustración mediante estampas realizadas por los principales grabadores franceses -Crozat tenía muy mala opinión de los demás6 - de los textos que Mariette fuera componiendo, que se referian de forma catalo- 
gráfica a las imágenes. Esta imprescindible integración entre imágenes y texto es lo que hace que sea esta obra pionera?.

El proyecto tuvo sus reveses. El principal fue el desarrollo paralelo del volumen Le Sacre de Louis XV con el que el rey quiso conmemorar su coronación ocurrida en 1722. Para ello despojó al poderoso Crozat de la mayor parte de los más de treinta grabadores que trabajaban en su proyecto por lo que éste adoptó un ritmo exasperante, incluso en fecha ya tan alejada de la coronación como 1728.

Caylus participó en él como grabador. Se habia iniciado en esta técnica gracias a su amigo Charles-Antoine Coypel, quien se convertiría a la larga también en su valedor ante la Academia. Cuando el conde leyó su discurso de ingreso como amateur en la Academia Real de Pintura y Escultura en 1731, la asistencia fue escasa. Coypel leyó de nuevo el mismo discurso un mes más tarde con resultados semejantes. Ante esto, Caylus no volvería a aparecer por ahí hasta 1747, cuando Coypel ya había progresado dentro de ella -llegaría a dirigirla- y él había sido elegido académico8. En el ínterin, las relaciones entre el conde y Coypel no se extinguieron pero sí se enfriaron durante un tiempo9.

Conviene recordar en este punto que este sistema de ilustración para conocer las obras de arte distantes o difícilmente accesibles fue el que se utilizó hasta la difusión de las técnicas de reproducción fotomecánica, lo que no ocurre hasta fechas cercanas a 1880 o, según otros, no antes del final de la Primera Guerra Mundial. Hasta ese momento de la difusión popular del libro ilustrado con fotografías el contacto con las obras de arte distantes era a través de las reproducciones hechas a mano que el mismo artista o, de forma más común, unos terceros realizaban de la obra primera. Y en ese proceso había más adulteraciones de las que puedan derivarse de la simple eliminación del color. No sólo las frecuentes inversiones de derecha a izquierda que realizaban los grabadores -con lo que el resultado, dado el sentido de lectura occidental, quedaba drásticamen-

6 Sobre el interés por los artistas según su nacionalidad, vid. JOULIE, Françoise: François Boucher et Pierre Crozat: Le role de la collection privée dans la formation d'un artiste au debut du XVIIlème siècle, en http://www.francois-boucher.net. Allí se sostiene que mientras Crozat valoraba realmente como artistas a los extranjeros, de los franceses opinaba que su labor no debía exceder de la condición de meros decoradores, lo que se demuestra por el hecho de que llamara a La Fosse y Watteau como pintores decoradores, no como artistas.

7 Para todo to referido al Recueil Crozat, vid. HASKELL, F.: op. cit.

8 CAYLUS, C. de: op.cit, pág. XXI.

9 MARIETTE, Pierre-Jean: Abecedario. París, F. de Nobele, 1966. Vol. 1, pág. 341. 
te modificado-, sino que el sistema de elaboración en conjunto suponia ya una modificación de resultados estupefacientes. Según Ivins, quien dedicó uno de sus títulos a este tema, no se trata de copias de copias sino de traducciones de traducciones 10 . Y, como recuerda Furió al respecto, "es precisamente la enorme importancia del grabado como medio de difusión del conocimiento por lo que conviene subrayar sus limitaciones en cuanto a su capacidad para transmitir una información visual objetiva"11. Si tenemos en cuenta que esto rige incluso para la fotografía, podemos aquilatar aún más la relatividad con la que deben tomarse estas reproducciones en cuanto tales. El conocimiento imperfecto de las obras que se comentan o copian no es un problema menor en la Historia del arte. Ivins ha puesto de manifiesto cómo el propio Lessing quedaba al albur de los grabadores al no haber visto jamás el Laocoonte, escultura que le inspiró un tratado que, sin embargo, resultó decisivo. Algo semejante cabe decir de Winckelmann.

Crozat se esforzó por que sus reproducciones fueran lo más exactas posibles. "Creo que hay razones poderosas -dice Haskell- para afirmar que en ninguna publicación anterior se habían tomado tantas molestias para conseguir reproducciones absolutamente fieles a las pinturas elegidas como modelo»12. Para ello eligió a los mejores grabadores, acercándoles a la obra original sin permitir que siguieran copias o traducciones -algo que sólo se hizo en una ocasión-, e incluso aplicó nuevas técnicas de grabado como la redescubierta por Paul-Ponce-Antoine Robert, protegido de Mariette, que unía el aguafuerte a la xilografía, consiguiendo un efecto semejante al de los dibujos lavados o realzados con blanco. Estas láminas, que figuraban entre las más destacadas del Recueil por su novedad, fueron realizadas conjuntamente por Nicolás Le Sueur y por Caylus.

Pese a sus inicios tardíos en la técnica del grabado, la dedicación del conde de Caylus y su voluntad de progreso en las disciplinas artísticas hicieron de él uno de los más destacados grabadores y dibujantes del momento. Su presencia en el Recueil Crozat lo demuestra. En él recibió la tarea en exclusiva de grabar los dibujos de la colección de Crozat. Gracias a los textos de Mariette "y a la calidad de las reproducciones de Caylus, el libro atrajo la atención cuidadosa de otros expertos" y el aumento de 100 a 120 láminas de cada uno de los volúmenes «fue posible gracias

10 IVINS, jr, W. M.: Imagen impresa y conocimiento. Análisis de la imagen prefotográfica. Barcelona, Gustavo Gili, 1975.

11 FURIÓ, Vicenç: Sociologia del arte. Madrid, Cátedra, 2000. pág. 272.

12 HASKELL, F.: op. cit., pág. 42. 
a la destreza del Conde de Caylus en copiar dibujos»13. Pero no fue ésta la única ocasión que tuvo de reproducir obras ajenas. En 1730 grabó las caricaturas de Leonardo que poseía Mariette, en 1745 grabó Les cris de Paris de Bouchardon y se conoce con el nombre abreviado de Recueil Caylus a la colección de 223 grabados que, tras dibujos de la colección del rey, realizara entre 1720 y 1729 con dedicación plena, según Mariette. A través de esta traducción algunos artistas conocieron las obras maestras del pasado y aumentaron su muestrario de personajes y paisajes ${ }^{14}$. No será infrecuente que estos repertorios se constituyan en la única referencia gráfica de obras hoy desaparecidas. Por eso, el trabajo pionero de Crozat, y con él el de Caylus, en la difusión fiel, masiva y conjunta de grandes obras maestras se reviste de una modernidad mayor e inusitada.

Desde luego que caben matizaciones en los adjetivos utilizados, como que la fidelidad estaba sujeta a las posibilidades del grabado; que la edición era tan sólo de 800 ejemplares y estaban destinados a los suscriptores más selectos de las esferas del poder europeo, aunque Crozat hablara de una clientela compuesta "des princes, des grands et du public", pues seguro que ese público, capaz de pagar 160 libras por dos volúmenes, se parecía poco al nuestro; que las grandes obras maestras procedian casi en su totalidad de la propia colección de Crozat, nada despreciable ni por cantidad ni por calidad: a su muerte se vendieron 19201 dibujos y 1369 grabados -de lo que se beneficiaron los pobres-y dejó en herencia unas 500 pinturas entre las que abundan los grandes nombres -Rafael, Reni, Carracci, Guercino, Tiziano, Giorgione, Tintoretto, Veronés, Rubens, Van Dyck, Rembrandt, Durero...-15; que su condición de obra de conjunto, todas las escuelas estarian representadas (un volumen por escuela: romana, florentina, veneciana, lombarda, boloñesa, flamenca, francesa y española) y Crozat se negó a vender las láminas sueltas según fueran saliendo de los talleres de los grabadores sucumbiendo a la presión de los compradores como era habitual, fue rota por el hecho de que los volúmenes iniciales quedaran en dos.

13 Ibid., págs. 64 y 52.

14 JOULIE, F.: op. cit., pág. 2.

15 CURNE DE SAINTE-PALAYE, Jean-Baptiste de la: Catalogue des tableaux du Cabinet de M. Crozat, Baron de Thiers. Ginebra, Minkoff Reprint, 1972. Reimpresión de la edición de París, 1755 . El barón de Thiers, Louis-Antoine Crozat, es el sobrino de Pierre Crozat y heredó lo principal de sus pinturas que pasarian a su muerte en 1770 a manos de Catalina de Rusia por mediación de Diderot, constituyendo la base del Ermitage. Se catalogan 393 pinturas en su casa, pero también se alude a otras de pequeño formato sin especificar su número. Obviamente, muchas de las atribuciones que alli figuran han cambiado. 
Pero esa voluntad de aunar el texto y la imagen y de darle cierto alcance didáctico sitúa a este proyecto, y con él al conde de Caylus, al principio de una línea en la que están los eslabones de las obras de Zanetti, de Stirling Maxwell, de Furtwängler, de Morelli, hasta llegar a los análisis de este fenómeno realizados por Benjamin y Malraux, autores de sendas obras que se dedican a analizar el impacto de la imagen en la era de su reproducción técnica y de la formación del museo imaginario16.

\section{Caylus, el escritor, impremeditado protagonista de un cambio influyente}

Pero la fama del conde de Caylus no deriva sólo de los grabados que produjera sino que debe antes la suerte o la desgracia con la que se asocia su nombre a su producción literaria. Entre ésta figuran los títulos que establecieron su fama desmedida de arcaizante, como su Mémoire sur la peinture à la encaustique et sur la peinture à la cire o los Nouveaux sujets de peinture et de sculpture, 17 además de sus discursos y de sus biografías de artistas y de otros que sirvieron de base a la refutación de Lessing, como los Tableaux tirés de l'lliade, de l'Odysée d'Homère, et de l'Énéide de Virgile, avec des observations générales sur le costume y la Histoire d'Hercule le Thébain, tirée de différents auteurs..., par l'auteur des tableaux tirés d'Homère et de Virgile 18. Son títulos estos dos últimos suficientemente elocuentes sobre su contenido y permiten alinearlos con los que desde la Antigüedad se desarrollan dentro de uno de los géneros más practicados en el campo de la literatura artística como es el de la descripción de obras de arte, ya sean reales o imaginarias, o de acontecimientos que permitan su reproducción plástica. Sólo se conserva el conocimiento de muchas obras del pasado gracias a la descripción de Plinio; y entre las descripciones de obras -aún no se sabe si existentes o imaginadas- están las de Filóstrato que permitieron a algunos artistas (re)componerlas, como abiertamente

16 ZANETTI, Anton Maria: Delie antiche statue Greche, e Romane, che nell'antisala della librería di S. Marco, $e$ in altri luoghi publicci di Venezia si trovano. Venecia, 1740 y 1743.2 vols.; STIRLING MAXWELL, William: Annals of the artists of Spain, Londres, 1848. 4 vols; FURTWÄNGLER, A.: Meisterwerke der Griechischen Plastik, 18931; FURTWÄNGLER, A. y URLICHS, H.L.: Greek \& Roman Sculpture, Londres, J.M. Dent \& Sons, 1914; MORELLI, Giovanni: Della pittura. Studii storico critici. Le gallerie Borghese e Doria Pamphili in Roma, Milán, Fratelli Treres, 1897; BENJAMIN, Walter: "La obra de arte en la era de su reproductibilidad técnica", en Discursos interrumpidos I. Madrid, Tecnos, 1973; MALRAUX, André: Las voces del silencio. Visión del arte. Buenos Aires, Emecé, 1956.

17 Ginebra, 1755 y Paris, 1755 respectivamente

18 Las dos en París en Tillard, en 1757 y 1758 respectivamente. 
imaginadas eran las que describía el desconocido Colonna en su Sueño de Polifilo al final del siglo XVI. Se utilizan estos nombres como ejemplo de esa práctica que comentamos y que aún hoy no se ha detenido. Ese juego de relaciones entre poesia y pintura es viejísimo. $Y$ Caylus juega un papel importante en su solución, aunque sea el de víctima propiciatoria.

Utilizar la poesía como fuente para que la imaginación extraiga de ella los más hermosos cuadros obliga a referirse a un momento de la historiografía en el que la antiquísima cuestión de la pintura como muta praedicatio, parece quedar definitivamente esclarecida. Lessing, en su tratado aparecido en Berlín en 1766, Laocoonte o de los límites en la pintura y la poesía, es el crítico que da a la solución forma definitiva, aunque no sea su conclusión tan novedosa como categórica19. Y en el momento en el que aparece la obra de Lessing era el conde de Caylus quien en mayor medida trataba la posibilidad de extraer composiciones pictóricas de los cuadros poéticos 20 . Es más, puede decirse que toda la argumentación de Lessing nace de una refutación de las ideas de Caylus, que había muerto el año anterior.

Lessing se apoya en tres frases de Caylus para desarrollar su implacable crítica de las dos ideas que caracterizan el sistema antiguo de valoración de las imágenes.

La primera de las frases la extrae Lessing de la Advertencia de Caylus a sus Tableaux tirés... En ella sostiene que un poeta y su poesía han de ser valorados en función de la cantidad de pinturas que puedan sugerir sus obras. Esta idea es la que justifica la existencia de su publicación, según el conde. La segunda la escribe Caylus pensando en la lliada de Homero: «Si este libro IV es notable por la variedad de las exhortaciones al combate, por la abundancia, diversidad y belleza de los caracteres y por el arte con que el poeta nos presenta a la multitud, que en breve debe poner en acción, no es menos cierto que es del todo inútil desde el punto de vista de la pintura». La tercera - «Puede ser muy bien que la pérdida de la vista haya sido la mayor semejanza que Milton tuvo con Homero»-le sir-

19 La respuesta a ese problema "ya se había empezado a entrever en las obras de Shaftesbury, Richardson, Dubos y Diderot. Lessing no inventó nada, pero supo expresar de una forma más decisiva y absoluta la diferencia existente entre pintura y poesía». VENTURI, Lionello: Historia de la crítica del arte. Barcelona, Gustavo Gili, 1982. pág.163.

20 Además de los Tableaux tirés... y de la Histoire d'Hercule... y anteriores en fechas, son sus discursos Réflexions sur la peinture y Del amateur, leídos en junio de 1747 y en septiembre de 1748 respectivamente, que tocan el tema de los libros como galerías para los pintores. Vid. CAYLUS, C. de: op. cit, págs. 126 y 136. 
ve de paso a Lessing para incidir, además de en lo errado de las ideas de Caylus, en su chovinismo21.

Las tres implican defender la equivalencia entre cuadros poéticos y cuadros pintados. Si el poeta puede ser prolijo en la creación de cuadros poéticos que despiertan la fantasía y producen, según Lessing, una enargie, una ilusión, establecer una analogía únicamente basada en la polisemia de la palabra "cuadro" es, lisa y llanamente, errar. Error en el que Caylus ha caído. Es decir, no todo cuadro poético puede ni tiene por qué poder concretarse en una forma pictórica, entre otras cosas porque su condición de arte temporal requeriría de una secuencia de imágenes. Desde el final del siglo XIX existe el cinematógrafo, pero eso es avanzar demasiado rápido en el tiempo.

De la relación entre pintura y poesía también se desprende otro motivo de crítica que será especialmente fructífero. Pensar que la pintura sólo puede extraer sus temas de la alta literatura, ya sea por su condición de Palabra de Dios hasta el Renacimiento, y, además, por su contrastado contenido humanístico después de él, a través de Ovidio en detrimento de Homero, supone mermar las posibilidades de la pintura o, por lo menos, establecer una injusta jerarquía de géneros.

La segunda idea básica del conde, y así mismo relacionada con la anterior y también equivocada, es la de convertir el tema, el asunto, en la fundamentación de la pintura, cuando el tema dista de encontrarse en una posición de privilegio con respecto a la disposición y la expresión que componga el pintor. Y Lessing aparece como un pensador moderno, incluso más que Winckelmann en este punto, pues mientras Lessing defiende el análisis de la obra en un contexto estético, Winckelmann parte de un concepto moral para su explicación22.

Winckelmann conocía muy bien la colección de Caylus a través del Recueil d'antiquites -en ocasiones aparece entre sus citas como Caylo o

21 Lessing se refiere a Caylus especialmente en los capítulos XII a XV. También aparece en los capitulos XVI, XXII y XXIV.

22 Extrañamente, para los hombres del siglo XVIII era más elevado Lessing que Winckelmann por esas razones, mientras que en el siglo XX se invierten las jerarquías. José Nicolás de Azara, comentador y compilador de la obra escrita de Mengs, encuentra más elevado a Lessing, que a Winckelmann, dentro de la postura sensualista propia de su tiempo según Mercedes ÁGUEDA. Vid. la introducción de MENGS, Antón Rafael: Tratado de la belleza, Madrid, COAAT, 1989. pág.35. L. VENTURI prefiere al segundo antes que al primero: "Resulta claro, por tanto, que era más elevada la crítica de Winckelmann que pretendía explicar una obra griega a partir de un concepto moral que la critica de Lessing la cual reduce a un nivel materialmente fisico aquella explicación». op.cit, pág. 164. 
Le Comte-23. Ambos coinciden en poner como ejemplo de poeta que no se presta a ser pintado a John Milton. Frente a él, "en Homero todo ha sido creado para la pintura»24, dice Winckelmann. Parece que está en esto más cerca de Caylus que de Lessing. En realidad Winckelmann vio publicada su Historia del arte en Drede en 1764, dos años antes de que apareciera el Laocoonte de Lessing, quien, sin embargo, mostraba en él su admiración rendida por Winckelmann. También a veces aplaudió a Caylus pero sólo por aquellas ocasiones en las que dice lo que no hay que hacer, no por aquéllas en las que se muestra partidario de determinada acción.

Con todo, Lessing no se opone a que la poesía pueda servir de motivo al pintor, ni que el poeta no pueda inspirarse en las pinturas, siempre y cuando ambos sean conscientes de la esencia espacial o temporal de sus artes respectivas, siempre y cuando conozcan los límites que separan a ambas. Él mismo delimita detalladamente el alcance de esos posibles préstamos. El ya conocido resultado de aquella discusión es el descubrimiento de que la poesía y la pintura tienen distinta naturaleza, y la consecuencia es que se abre un nuevo período no ya sólo en la comprensión de la esencia de cada una de las artes, sino en la forma de tratar el tema que hasta ahora había imperado en ellas. Si la narración era la forma de hacerlo, y los temas eran los de la narración, ahora que el poema y la pintura ya no son intercambiables, los trasvases subsiguientes entre las dos artes no serán meras traducciones de lenguaje.

Tras Lessing, Caylus quedaba retratado como un retrógrado merecedor de los ataques de los protagonistas del cambio de régimen. Hay quienes, con posterioridad, han defendido la liberalidad del conde, con el riesgo que supone indisponerse con aquellos adalides. Más adelante volveremos sobre esto. Antes nos detendremos a ver cómo, en pleno torbellino de modernidad y en la génesis de la misma, sigue abierta esa vieja disquisición.

Charles Baudelaire, acostumbrado a soñar museos y a recordar todos aquellos que no conoció -es otra vez Malraux el que se toma la molestia de recordar los escasos viajes de quien quizá por ello tanto nos invite a realizarlos-, los encuentra por doquier, especialmente en los textos, en la misma savia que lo hiciera el conde de Caylus. Es cierto que para él el

23 WINCKELMANN, Johannes Joachim: Historia del arte en la Antigüedad. Parte I, libro II, capítulo VI y Parte II, capítulo II, notas.

24 Ibid. Parte I, libro I, capítulo III. 
arte filosófico, herético y decadente, mistifica toda forma de expresión: « $¿$ Se debe a una fatalidad de las decadencias el que hoy cada arte manifieste el deseo de usurpar el arte vecino, y que los pintores introduzcan gamas musicales en la pintura, los escultores, color en la escultura, los literatos, medios plásticos en la literatura, y otros artistas, (...) una suerte de filosofía enciclopédica en el arte plástico mismo?»25. Pero, curiosamente, lo hace de la misma forma que la modernidad toma para Baudelaire carta de naturaleza: «David, Guérin y Girodet inflamaban su espíritu al contacto de Homero, de Virgilio, de Racine y de Ossian. Delacroix fue el conmovedor traductor de Shakespeare, de Dante, de Byron y de Ariosto"26. Él mismo evoca en verso los colores de Delacroix, y lo explica. $Y$ otra vez sobre Delacroix dice: «La lectura de los poetas dejaba en él imágenes grandiosas y rápidamente definidas, colores acabados, por así decirlo"27. No representa esto sino el paso último en la concreción que Caylus dejara de dar como humilde amateur en su extracción de temas -y no sólo de eso- de las obras de Virgilio y Homero. Exactamente igual que Baudelaire, el crítico del arte de la vida moderna, hace ante la obra de E. A. Poe: « ¿Recuerdan un cuadro ( $j e n$ verdad es un cuadro!) escrito por la pluma más poderosa de esta época, que tiene por título El hombre de la multitud?»28.

Cien años separan las obras de Caylus y Baudelaire. $Y$ siglo y medio el presente de los escritos del poeta. $Y$ aún no se han extinguido las invitaciones a transitar el camino entre la poesía y la pintura. La pintura sólo es poesía que hay que saber traducir a verso (Wilde) y nosotros el ojo que escucha (Claudel). porque oímos todas las voces silenciosas del museo. Aby Warburg soñó con un proyecto que fuera capaz de reflejar tan sólo con imágenes toda una concepción del universo29. Y Pierre Francastel anunció a la generación que piense con imágenes y que termine incluso por desterrar a los últimos representantes del libro30. Esa generación que se dice que vive ahora.

25 BAUDELAIRE, Charles: «El arte filosófico", en Salones y otros escritos sobre arte. Madrid, Visor, 1996. pág. 399.

26 BAUDELAIRE, Ch.: “La obra y la vida de Eugène Delacroix", en op. cit., pág. 326.

27 Ibid.

28 BAUDELAIRE, Ch.: «El pintor de la vida moderna», en op. cit., pág. 357.

29 GOMBRICH, Ernst Hans: Aby Warburg. Una biografía intelectual. Madrid, Alianza, 1992.

30 FRANCASTEL, Pierre: “Arte e historia: dimensión y medida de las civilizaciones", en VV.AA.: Hacia una nueva historia. Madrid, Akal, 1976. pág. 60. 


\section{Caylus, coleccionista y promotor de las artes, cuando nace el museo}

Caylus, con la animosidad y la dedicación que incluso sus detractores le reconocian, sumó a su interés por lo artístico como creador y tratadista su condición de promotor de las artes desde el puesto del mecenas, si bien con cierta humildad pues su riqueza no fue considerable hasta los últimos años de su vida, cuando su tío le benefició como heredero. Sin embargo, artistas como Vien, Trémollières, Vassé, Lagrenée y Bouchardon se vieron favorecidos con anterioridad por su munificencia. Su amigo de la juventud, Watteau, le dio clases de dibujo a cambio del pago de habitaciones en las que dibujar a las modelos también proporcionadas por el conde. En 1759 instituyó un concurso anual de dibujo de expresión. Previamente había creado otro en la Académie de Inscriptions et Belles-Lettres, de la que también era miembro, para premiar a quien mejor discurriera sobre un tema de la Antigüedad propuesto por los académicos. Estas instituciones fueron agasajadas con sus frecuentes regalos, entre ellos el retrato de Du Fresnoy realizado por Le Brun, pero también con otros más inusitados, como una piel del león, una tabla con ruedas para transportar pinturas o un esqueleto que posteriormente aprovechó para proponer otro concurso de dibujo una vez dispuesto a la manera de una escultura antigua.

Su labor como coleccionista quizás sea más trascendente. En ella destaca su colección de monedas, piedras grabadas y otras antigüedades. El resto de sus objetos apenas eran algunos efectos curiosos, a decir de Mariette. Perdido el inventario del mobiliario de su casa realizado a su muerte, se sabe que tenía pocos cuadros y mal conservados. A cambio, el número de bibelots, vasos y bronces era crecido. La colección de monedas y antigüedades dio lugar a una vasta empresa: la elaboración de un Recueil d'antiquites en siete volúmenes que aparecieron entre 1752 y 1767 en París en la que propio conde grabó las reproducciones.

No se puede decir que haya motivos para pensar que Caylus imaginara un museo abierto al público, moderno. Sin embargo, es entonces cuando están naciendo los principales, entre ellos el British Museum, erigido en 1753 sobre un montón de volúmenes y antigüedades, como será habitual en este momento de paso de las Wunderkammern al museo. Menos de treinta años separan su muerte de la apertura del Louvre en 1793, aunque sean años larguísimos. Previamente, allí se realizaban los Salones. Es en las críticas que de ellos hace Caylus en donde se puede rastrear mínimamente la medida de su interés por un público cada vez más 
numeroso e instruido por las obras de arte. Allí sostiene que todo el mundo tiene inicialmente un gusto por el arte y que el gusto es capaz de formarse. Ciertas ideas ilustradas parecen despuntar.

Esa labor de crítica del Salón será continuada por Diderot, pero con un criterio muy diferente. Mientras Caylus asegura pretender «transmitir las impresiones favorables del público no como juez sino como historiador»31, es sabido que Diderot va a crear con sus críticas la crítica de arte como hoy la conocemos32: subjetiva, en la que el crítico se recrea a si mismo a través de la obra que contempla en un potente juego imaginativo que traspasa al público de forma arriesgada y a veces incontrolable, tanto más desde que las imágenes abundan y se mezclan y los museos y las exposiciones rebosan de un público ajeno a las críticas y a la vez sometido a ellas, ávido de productos con más imágenes, como el de Crozat, ante las que su formación, exclusivamente práctica, a veces resulta insuficiente.

\section{Caylus o la muerte historiográfica}

Charles-Nicolas Cochin II, a quien la muerte del conde ablandó el ánimo hasta el punto de hacerle olvidar su rechazo por él y dedicarle una remembranza, menciona la existencia dentro de la Academia de un grupo Anticaylus. Si Diderot hubiera sido un buen líder de esa facción, sin duda el mejor secretario que ésta pudo tener por su gestión de la crítica fue Jean-François Marmontel. En sus Memorias, Marmontel recuerda a Caylus con una desafección especial y le presenta como un mezquino vanidoso que se dedica a fruslerías sin renunciar a regalarse los oídos con la música celestial de la fama. Por muy vívido que pueda resultarnos esta caracterización moral por recordarnos siempre a alguien próximo, no por eso es más justo seguir a Marmontel en su opinión, condenando a Caylus a disfrazarse eternamente con un traje ridículo. Desde luego que su voz representa a otras numerosas, las de los Anticaylus, pero quien termina esa declaración de rechazo intenso con una frase tan afectada - «Yo tenía por él esa especie de antipatía natural que los hombres simples y verdaderos tienen siempre por los charlatanes"- 33 no parece merecedor de un crédito sólido.

31 CAYLUS, C. de: op. cit., pág. 195.

32 Vid. los textos de CALVO SERRALLER, Francisco: "La crítica de arte", en CALVO SERRALLER, Francisco (ed.): Los espectáculos del arte. Instituciones y funciones del arte contemporáneo. Barcelona, Tusquets, 1993 y "Orígenes de un género: la crítica de arte", en BOZAL, Valeriano (ed.): Historia de las ideas estéticas y de las teorias artisticas contemporáneas. Madrid, Visor, 1996. Vol. I.

33 Vid. MARIETTE, P.-J.: op. cit., pág. 343. 
Mariette compartió con Caylus toda una vida y si él dice que su carácter era bilioso y explosivo, sin duda que lo era. Pero el objetivo no es emitir un juicio moral sobre el conde sino saber por qué el que emitieron algunos pudo establecer un resultado historiográfico semejante y si este debe revisarse al alza.

Las líneas maestras de los ataques a la imagen del conde a considerar son dos, pues las restantes -libertino, iracundo, soberbio, incluso meticuloso34- obedecen a una clasificación improcedente y son más denostables cuanto más oscurecen una aportación histórica mensurable. Esas líneas maestras son la referida al excesivo celo en el sostenimiento de los artistas a los que patrocinaba y en su participación en las Academias a las que perteneció para dirigirlos hacia unos postulados estéticos arcaizantes y su escasa talla científica, utilizando términos actuales.

La primera se sostiene en el apoyo prestado a Vien, Lagrenée y Bouchardon. Vien y Lagrenée hicieron cuadros famosos en su momento que utilizaban temas clásicos, algunos de ellos -como El mercado de los amorcillos (1763) - tomados de los frescos de Herculano que conoció y copió Caylus lo que a la larga le enemistó con la corte napolitana. En esas pinturas empiezan a reproducirse muebles que los anticuarios escogian de entre las pinturas de los vasos griegos y romanos. Que la precisión era importante da medida Jean-Baptiste Greuze quien vio cómo eran criticados los detalles de su Septimio Severo amonestando a Caracalla (1769) de tal manera que impidió su ingreso en la Academia como pintor de historia, teniendo que hacerlo por la más humilde vía de pintor de género. Esos artistas y sus pinturas muestran con precisión hasta qué punto el arte de la época estaba preparado para adoptar la fórmula del neoclasicismo y que los desvelos de Caylus por conseguir un estilo severo y adecuado a la técnica de la encáustica recuperada de entre los textos de Plinio no quedaban fuera de lugar, dejando abierto el camino para otro dictador de las artes como no lo había en Francia desde los días de Le Brun: Jacques-Louis David35.

Pero a la vez, Caylus tomó partido por el arte contemporáneo frente a los verdaderos restauradores de la Antigüedad36. De ello dan muestra

34 Caylus firmaba las novelas licenciosas que producia la Société du bout du banc y escribió muchas de ellas. También parece que desarrolló ese interés en el campo de la plástica y se sospecha que eran de ese tono los dibujos que Watteau insistia en que destruyera al saber cercana su muerte y en los que colaboraria. Tal vez para purgar sus remordimientos, si es que los tuvo quien no quiso recibir sacramento alguno mientras se veía morir con detalle. Caylus escribió unos Souvenirs reputados por su espiritualidad.

35 LUCIE-SMITH, Edward: French Painting. Londres, Thames and Hudson, 1971. págs. 170-172. 
sus biografías de artistas vivos y en absoluto arcaizantes como Watteau, quien dotaba a sus personajes de una introspección que ha sido destacada como eminentemente moderna.

Junto a aquella corriente realmente arcaizante, coexistió otra incipiente que va a terminar provocando el nacimiento de una de las características de la modernidad visible en la obra de Goya, tan admirado por iniciarla por Baudelaire y Malraux. En ese nacimiento participó Bouchardon con sus estudios d'après nature para Les Cris de Paris, una representación de tipos populares que grabó Caylus y que son uno de los precedentes de la obra de Goya en virtud de su observación del pueblo llano37.

Recomendaciones a la observación del natural ya aparecen en los discursos y las cartas de Caylus, unas fuentes que parecen desatendidas a la hora de fijar su imagen. En una de sus cartas aconseja a un joven viajero por Italia que imite a la naturaleza como hace el arte antes que copiar modelos sin vida38 y en uno de sus discursos propone extraer la inspiración de la naturaleza utilizando el gusto como medio de discernimiento entre lo verdadero y lo falso39. A Caylus se le ha llegado a comparar por su amor a la naturaleza y a la belleza y por su liberalidad con un Roger de Piles, quien fue consejero de compras de Crozat y de quien el conde hizo un elogio ante la Academia 40 .

Con el tiempo, algunos puntos de la crítica contra Caylus se han convertido en motivos de encomio. Si la segunda de las líneas maestras de la imagen negativa creada por sus detractores era la falta de altura de sus estudios y le retrataban como un coleccionista de fragmentos antiguos sin interés, el hecho de que dedicara su atención no sólo a las obras maestras sino también a los objetos cotidianos, a la cultura material más prosaica, le descubre como un arqueólogo adelantado hasta el punto de merecer un lugar parejo al que ocupa Winckelmannn en las aportaciones a esa disciplina científica 41 .

Caylus vive en un momento en el que se están gestando un nuevo ciclo histórico y también artístico. Una de las notas de ese nuevo mun-

36 VENTURI, L.: op.cit., pág. 151.

37 Vid. BOZAL, Valeriano: Imagen de Goya. Barcelona, Lumen, 1983. Capítulo I: "D'après nature», especialmente págs. 28 y ss.

38 CAYLUS, C. de: op. cit., pág. XXXIII.

39 ibid., pág. 131.

40 lbid., pág.XXX.

41 RICE, D.: op.cit., pág. 121. 
do va a ser el aumento de la velocidad y la intensidad en la comunicación, y una de sus vías es la reproducción de imágenes por medios cada vez más fieles y en mayor cantidad y que incluso lleguen a sustituir al texto. En el otro extremo del camino de la creación del conjunto de imágenes con las que convivimos está Caylus. 